\title{
Multiple Proxies on the Paleoenvironment of the Early Cambrian Marine Black Rock Series in the Tarim Basin, NW China: Molybdenum Isotope and Trace Element Evidence
}

\author{
Chunyan Yao, Weimin Guo, Junan Liu, Hanwu Li \\ Nanjing Center, China Geology Survey, Nanjing, China \\ Email:ycyan@126.com,mwguo@163.com,junan2003@126.com,lihanwu@foxmail.com
}

How to cite this paper: Yao, C.Y., Guo, W.M., Liu, J.N. and Li, H.W. (2017) Multiple Proxies on the Paleoenvironment of the Early Cambrian Marine Black Rock Series in the Tarim Basin, NW China: Molybdenum Isotope and Trace Element Evidence. International Journal of Geosciences, 8, 965-983.

https://doi.org/10.4236/ijg.2017.88055

Received: June 19, 2017

Accepted: August 18, 2017

Published: August 21, 2017

Copyright $\odot 2017$ by authors and Scientific Research Publishing Inc. This work is licensed under the Creative Commons Attribution International License (CC BY 4.0).

http://creativecommons.org/licenses/by/4.0/

\begin{abstract}
The early Cambrian carbonaceous shale and laminated chert-phosphorite assemble (the black rock series) are widespread at the northwest margin of the Tarim Basin, Northwest China. In combination with previously reported data, we present stable molybdenum isotope $\left(\delta^{8 / 95} \mathrm{Mo}\right)$, TOC, and redox-sensitive trace elements to evaluate the sedimentary conditions in early Cambrian water column during the deposition of the black rock series in the Tarim Basin. Redox variation was documented based on enrichment factors $\left(\mathrm{Mo}_{\mathrm{EF}}, \mathrm{V}_{\mathrm{EF}}\right.$, and $\left.\mathrm{U}_{\mathrm{EF}}\right)$ and redox-sensitiv elements ratios $(\mathrm{Ni} / \mathrm{Co}, \mathrm{V} / \mathrm{Cr}, \delta \mathrm{U})$, etc. During the early Cambrian, there was transgressive event, and the sea level continues to rise. In the basal Cambrian, laminated chert-phosphorite assemble with low TOC concentrations suggest the oxic sedimentary condition in a restricted basin. Light Mo isotope values and redox sensitive elements enrichment in the carbonaceous shale layer indicate lack oxygenic sedimentary condition, and was suboxic/anoxic conditions during the transgressive phase. The hydrothermal fluids from the open ocean affected the whole deposition process of the black rock series.
\end{abstract}

\section{Keywords}

Molybdenum Isotope, Trace Element, Paleo-Environment, Early Cambrian, Tarim Basin

\section{Introduction}

The molybdenum (Mo) isotope system, together with trace metal geochemistry have been taken as the indicator of the redox conditions in ancient paleo-envi- 
ronments [1]-[7]. The rate and completeness of removal of Mo to sediment differs among 1) oxic $\left(\mathrm{O}_{2}\right.$ concentration in bottom waters, $\left.\left[\mathrm{O}_{2}\right]>2 \mathrm{mLO}_{2} / \mathrm{LH}_{2} \mathrm{O}\right)$, 2) suboxic to weakly euxinic $\left.\left(\left[\mathrm{O}_{2}\right]<0.2 \mathrm{mLO}_{2} / \mathrm{LH}_{2} \mathrm{O},\left[\mathrm{H}_{2} \mathrm{~S}\right]<11 \mu \mathrm{m}\right), 3\right)$ strongly euxinic $\left(\left[\mathrm{H}_{2} \mathrm{~S}\right]>11 \mu \mathrm{m}\right)$ in water-column redox facies [6] [8] [9]. A model for interpreting primary redox environments from the $\delta^{8 / 95}$ Mo of organic carbon rich mudrock deposit has been defined [10]. In fully oxic conditions, Mo would be mainly adsorbed to Mn-oxides, and little Mo enrichment below sedimentwater interface [10]. In suboxic and weakly euxinic conditions, Mo isotopic fractionation might be between that of oxic and strongly euxinic sediments [2] [11]. In anoxic seawater and pore fluids, Mo is converted to the particle reactive thiomolybdate anion $\left(\mathrm{MoO}_{\mathrm{x}} \mathrm{S}_{4-\mathrm{x}}^{2-}\right)(\mathrm{x}=0$ to 3) [12] [13]. In euxinic sediments $\left(\left[\mathrm{H}_{2} \mathrm{~S}\right]>11 \mu \mathrm{m}\right)$, Mo is turned into tetrathiomolybdate $\left(\mathrm{MoS}_{4}^{2-}\right)$ and $\delta^{88 / 95} \mathrm{Mo}$ has heavy isotope value closer to that of modern ocean water (2.3\%o) [11] [14].

Trace elements, such as Mo, U, V, etc., are highly sensitive to redox changes in the water column and are highly enriched in the reducing sediment, potentially making them and their ratios for important proxies for paleo-redox conditions [15] [16] [17].

The early Cambrian represents a unique period in Earth history characterized by global environment and biological changes [18] [19]. Lower Cambrian organic-rich black shales have been discovered in North America, southern Australia, parts of European, and Asia [7] [20] [21] [22] [23]. A possible global ocean anoxia event could be occurred during the early Cambrian period, and numerous geochemical proxies (such as $\mathrm{C}, \mathrm{S}$ isotopes), also support this suggestion.

In China, the Lower Cambrian sedimentary strata, containing black shales and cherts, occur on the Yangtze and Tarim Platforms [7] [23] [24] [25] [26] [27]. Previous research has been mainly focused on the Yangtze Platform about the paleo-environment during the early Cambrian period [7] [26] [28] [29] [30] [31]. However, there is no equivalent research on the sedimentary sequence of the Tarim Platform. In this study, we investigated black rock series (containing phosphorite, phosphorous chert, chert, and carbonaceous shale) from the Lower Cambrian Sugetbrak section, Akesu-Wushi area, Tarim Basin. The joint application of $\delta^{8 / 95} \mathrm{Mo}$, TOC concentrations and trace element geochemistry attempts to contribute to an understanding of the paleo-environment of Early Cambrian seawater on the Northwest China.

\section{Geological Setting and Sampling}

The Tarim Basin, located within the Xinjiang Uygur Autonomous Region of northwestern China, is one of the largest hydrocarbon-bearing intracontinental basins in the world [23]. The Tarim Basin is surrounded by the orogenic belts of Tienshan Mountains to the north, the western Kunlun Mountains to the south, and the Central-Southern Altyn Tagh Mountains to the southeast [32]. The strata of the Cambrian in the Tarim Basin consist of the Yurtus, Xiaoerblaq and 
Wusonger Formations in an ascending order [33]. The Yurtus Formation unconformably overlies the dolomite of the Ediacaran Qigeblaq Formation, and conformably underlies the trilobite-bearing limestone of the Xiaoerblaq Formation [33]. Lithologically, the Yurtus Formation is composed of basal black rock series and limestone above those basal rocks. The black rock series are over- and underlain by limestones, suggesting a shallow marine environment [23]. The black rock series contain bedded black chert with dark colored phosphatic granule layers, and carbonaceous shale (Figure 1(c)).

The Sugetbrak section, which is one of the well-known sections of the Akesu-Wushi area, is located in the northern margin of the Tarim Basin (Figure 1(a), Figure 1(b)) [23] [34] [35] [36] [37] According to paleontological studies in this area, the Asteridium-Heliosphaeridium-Comasphaeridium (AHC) acritarch assemblage zone, which was restricted to the Meishucunian Stage [35], was found in the black rock series at the base of the Yurtus Formation.

The measured thickness of the Sugetbrak section is $2.06 \mathrm{~m}$. This section consists of interbedded chert-phosphorite assemblages $(1.04 \mathrm{~m})$ and the carbonaceous shale $(1.02 \mathrm{~m})$ of the Early Cambrian Yurtus Formation in an ascending order (Figure $1(\mathrm{c})$ ). A total of 12 chert-phosphorite samples and 4 carbonaceous shale samples were collected from the lower Yurtus Formation in the Sugetbrak
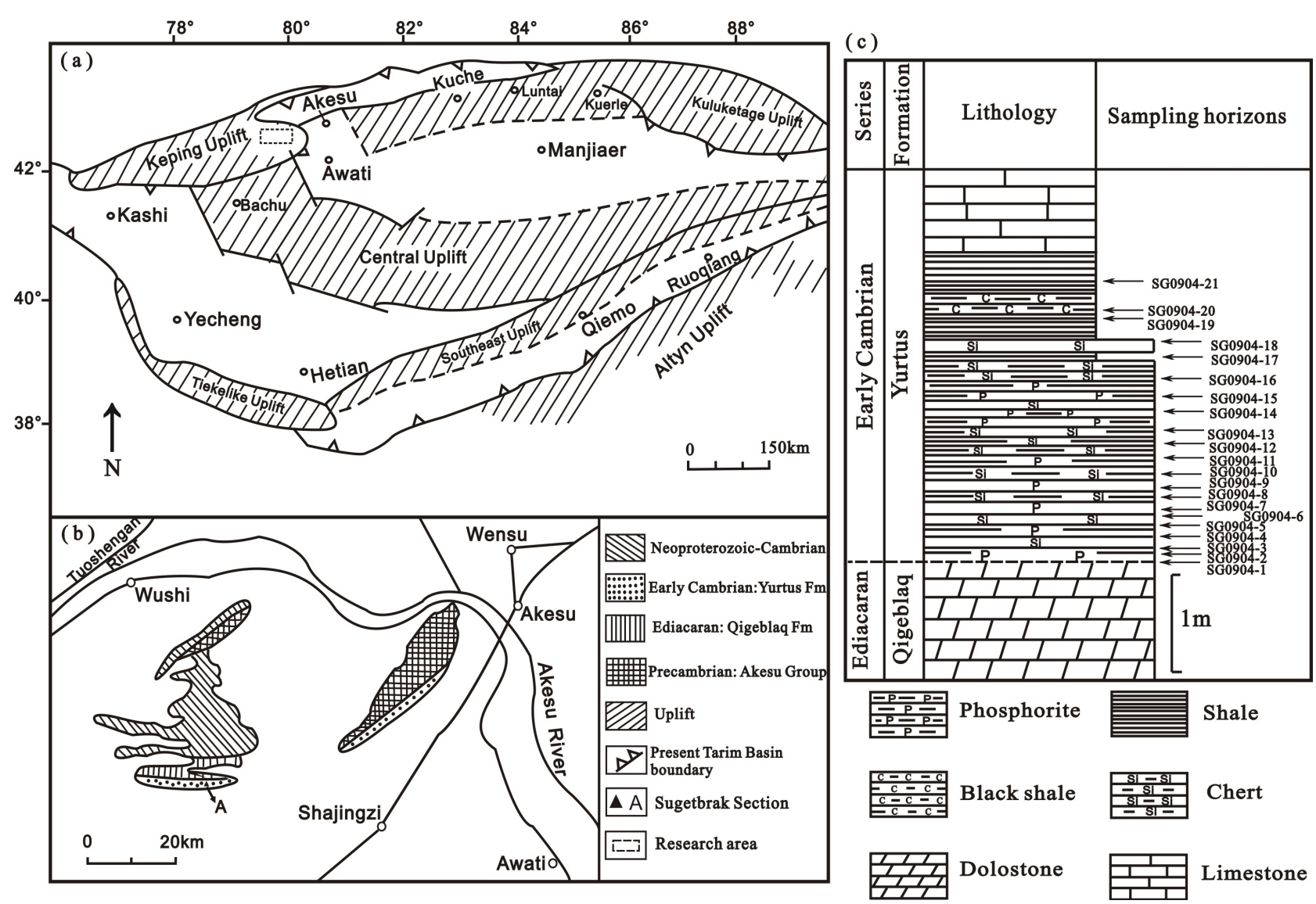

Figure 1. (a) Position of the study area. Modified after reference [23]; (b) geological setting of the studied section and the tectonic setting. Modified after reference [37]; (c) lithostratigraphy and the sampling horizons of the Sugetbrak section. 
section (Figure 1(c)).

\section{Samples Preparation and Analytical Methods}

Fresh samples were directly selected indoors. The samples were washed with deionized water and ground to 200-mesh using an agate mortar for chemical analysis. Trace elements, TOC, and Mo isotope were analyzed in this study.

\subsection{Trace Element and TOC Analysis}

A routine HR/ICP-MS method was used. For each analysis, a $50 \mathrm{mg}$ sample of 200-mesh powder was accurately weighed and placed into a Teflon dissolving can. The sample was leached with $1 \mathrm{~mL}$ of $\mathrm{HF}$ at $150^{\circ} \mathrm{C}$ and boiled to dryness to remove carbonate and calcium phosphate minerals. Then, the residues were fully dissolved in $1.0 \mathrm{~mL}$ of $\mathrm{HF}$ and $0.6 \mathrm{~mL}$ of $\mathrm{HNO}_{3}$. The mixture was placed into a Teflon dissolving can and heated at $190^{\circ} \mathrm{C}$ for at least $96 \mathrm{~h}$. The solution was evaporated into an emulsion to remove excess HF. The residue was dissolved in $1 \mathrm{~mL}$ of concentrated $\mathrm{HNO}_{3}$ and evaporated to an emulsion (this step was repeated twice). The residue was dissolved in $1.6 \mathrm{~mL}$ of $\mathrm{HNO}_{3}$ and heated at $140^{\circ} \mathrm{C}$ for $3 \mathrm{~h}$ to $5 \mathrm{~h}$, and then transferred into a $50 \mathrm{~mL}$ centrifuge tube. The resultant heated residue was mixed with $1 \mathrm{~mL}$ of $500 \mathrm{ppb} \mathrm{Rb}$ internal standard, diluted to $50 \mathrm{~mL}$, and analyzed by HR/ICP-MS at the State Key Laboratory for Mineral Deposits Research of Nanjing University. The analytical precision of elemental concentrations was generally better than $5 \%$.

The same set of 200-mesh powder samples was analyzed for TOC composition. The powder samples were reacted with $1 \mathrm{~mol} / \mathrm{L} \mathrm{HCl}$ in a water bath at $50^{\circ} \mathrm{C}$ for at least $48 \mathrm{~h}$ (adding $1 \mathrm{~mol} / \mathrm{L} \mathrm{HCl}$ twice) until no further reaction was observed. The solutions were washed with deionized water until $\mathrm{pH} 7$, and the residue was dried and ground to 200-mesh. Samples were analyzed using a FLASH EA1112 elemental analytical instrument at the Nanjing Institute of Geography and Limnology of the Chinese Academy of Sciences.

\subsection{Mo Isotope Analyses}

A detailed description of the analytical techniques is given in Zhang et al. (2009) and Wen et al. (2010, 2011) [38] [39] [40], and only a brief summary is presented here. Sample powders with an equivalent of $>100 \mathrm{ng}$ were oxidized at $600^{\circ} \mathrm{C}$ for $8 \mathrm{~h}$, and then transferred to a Teflon beaker. Samples were digested using a mixture of $\mathrm{HF}$ and $\mathrm{HNO}_{3}(1: 2)$ at $100^{\circ} \mathrm{C}$ for at least $16 \mathrm{~h}$ until the samples were completely dissolved. An improved anion/cation exchange resin doublecolumn procedure was used to separate Mo from natural samples [38].

The Mo isotopic measurements were performed at the State Key Laboratory of Ore Deposit Geochemistry, Institute of Geochemistry, Chinese Academy of Sciences, using an Isoprobe MC-ICP-MS. To correct isotopic drifts of the instrument, a sample-standard bracketing technique was employed [39]. The working Mo standard solution was prepared from a newly standard Mo solution 
(NIST SRM 3134, Merck, JMC, and Aldrich). For data presentation the $8^{88 / 95} \mathrm{Mo}$ ratio is used. The external standard reproducibility is at or below $0.1 \%$ for the $\delta^{88 / 95}$ Mo ratio. The value of $\delta^{88 / 95}$ Mo is defined by the following Equation (1).

$$
\delta^{98 / 95} \mathrm{Mo}(\% 0)=\left[\left(\delta^{98 / 95} \mathrm{Mo}\right)_{\text {sample }} /\left(\delta^{98 / 95} \mathrm{Mo}\right)_{\text {standard }}-1\right] \times 1000
$$

\section{Analytical Results}

The $8^{98 / 95}$ Mo values, TOC, and trace element concentrations (such as Mo, $\mathrm{U}$, and $\mathrm{V}$, et al.) and their ratios are presented in Table 1.

\subsection{Mo Isotope}

Mo isotopic data are presented in Table 1, and their stratigraphic trend is shown in Figure 2. The measured $\delta^{88 / 95} \mathrm{Mo}$ values of the samples vary from $-0.17 \%$ to $1.56 \%$. We obtained one negative shift at the base of the Yurtus formation (N1, sample SG0904-2, 3, 4, 5, 6), one positive shift (P1) immediately with one negative shift in the carbonaceous shale layer (N2) (Figure 2).

\subsection{Trace Elements and TOC}

The trace element results and their selected ratios are shown in Table 1 . Enrichment factors are calculated by normalizing each trace element to aluminium (Al) in concentration, which is assumed to represent the detrial influx, and
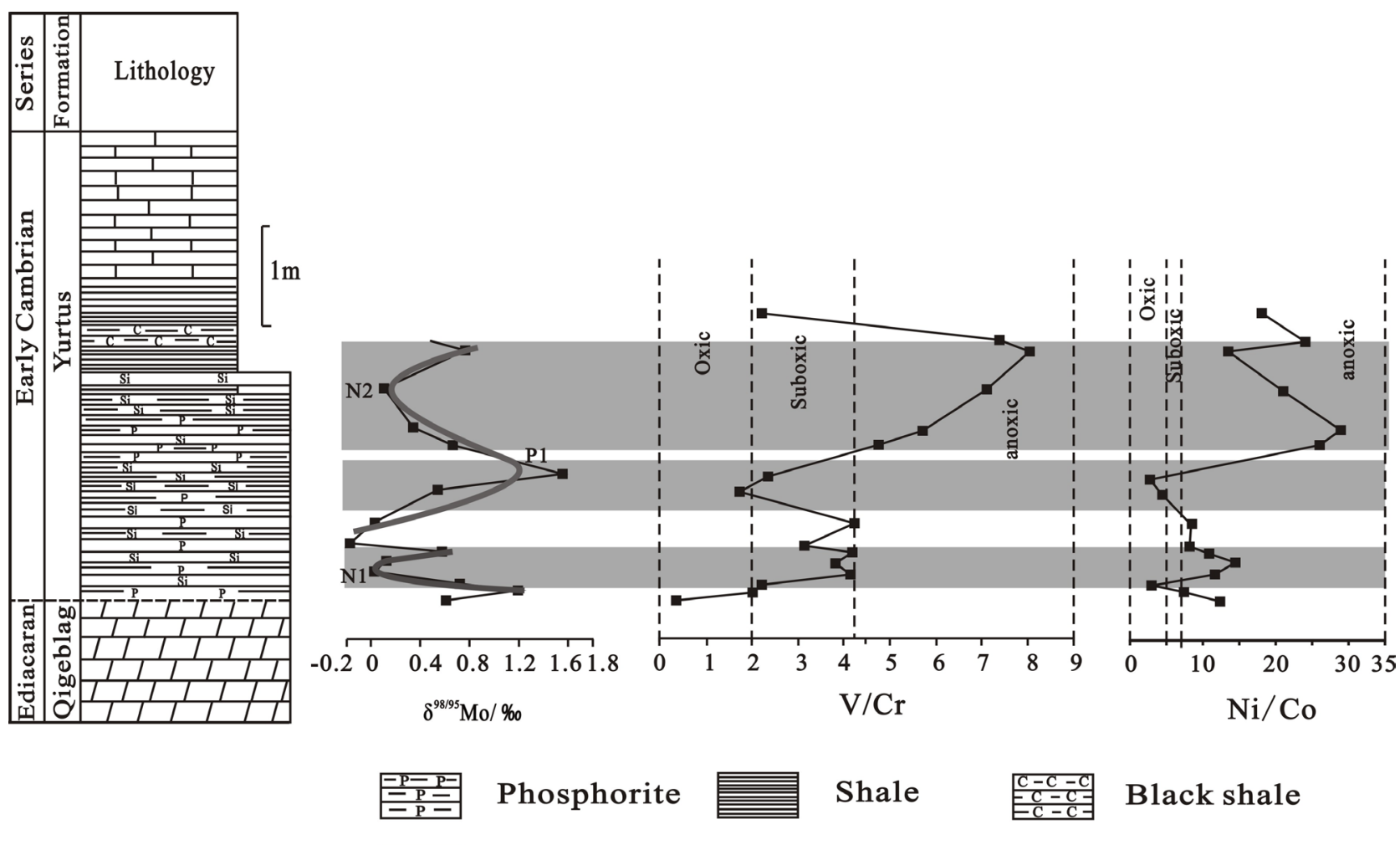

Shale

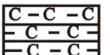

Black shale
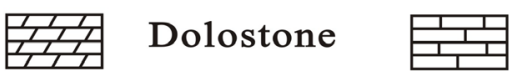

Limestone

Chert

Figure 2. Stratigraphic distribution of elemental ratios and Mo isotopic compositions. 
Table 1. The $\delta^{88 / 95}$ Mo values, TOC, and redox sensitive element data and ratios of the Sugetbrak section, Tarim Basin.

\begin{tabular}{|c|c|c|c|c|c|c|c|c|c|c|c|c|}
\hline$c_{0}-1$ & $T \cdot 4$ 1 & Depth & $8^{98 / 95} \mathrm{Mo}$ & $\mathrm{V}$ & $\mathrm{Cr}$ & Co & $\mathrm{Ni}$ & Mo & Th & $\mathrm{U}$ & $\mathrm{Al}$ & TOC \\
\hline Samples & Litnology & (m) & $(\%)$ & (ppm) & (ppm) & (ppm) & (ppm) & (ppm) & (ppm) & (ppm) & $\%$ & $\%$ \\
\hline SG0904-1 & Phosphorite & 0.00 & 0.61 & 60.00 & 178.00 & 11.60 & 143.00 & 60.70 & 0.44 & 202.00 & 0.29 & 0.32 \\
\hline SG0904-2 & Phosphorite & 0.20 & 1.19 & 371.00 & 184.00 & 5.20 & 38.30 & 9.91 & 2.14 & 47.00 & 0.86 & 0.60 \\
\hline SG0904-3 & $\begin{array}{c}\text { Phosphorous } \\
\text { chert }\end{array}$ & 0.30 & 0.73 & 409.00 & 185.00 & 14.50 & 45.00 & 15.00 & 0.90 & 24.50 & 0.57 & 0.14 \\
\hline SG0904-4 & Chert & 0.35 & 0.03 & 414.00 & 100.00 & 3.74 & 43.50 & 21.90 & 0.34 & 10.70 & 0.42 & 0.10 \\
\hline SG0904-5 & Phosphorite & 0.40 & 0.13 & 962.00 & 252.00 & 2.39 & 34.50 & 18.90 & 2.44 & 36.30 & 0.84 & 0.22 \\
\hline SG0904-6 & $\begin{array}{c}\text { Phosphorous } \\
\text { chert }\end{array}$ & 0.46 & 0.58 & 686.00 & 164.00 & 4.39 & 47.50 & 56.00 & 0.54 & 8.85 & 0.43 & 0.39 \\
\hline SG0904-7 & Phosphorite & 0.50 & -0.17 & 710.00 & 227.00 & 7.18 & 58.40 & 33.70 & 1.79 & 26.70 & 0.48 & 0.49 \\
\hline SG0904-9 & Phosphorite & 0.60 & 0.03 & 704.00 & 167.00 & 5.77 & 48.20 & 25.60 & 0.61 & 52.30 & 0.28 & 0.94 \\
\hline SG0904-11 & $\begin{array}{c}\text { Phosphorous } \\
\text { chert }\end{array}$ & 0.75 & 0.54 & 847.00 & 489.00 & 5.09 & 22.20 & 4.82 & 1.85 & 4.44 & 1.60 & 0.07 \\
\hline SG0904-12 & Chert & 0.80 & 1.56 & 292.00 & 124.00 & 14.60 & 39.60 & 37.30 & 0.25 & 7.42 & 0.32 & 0.05 \\
\hline SG0904-14 & Phosphorite & 0.97 & 0.66 & 442.00 & 92.80 & 1.59 & 41.30 & 99.00 & 0.79 & 45.40 & 0.47 & 0.68 \\
\hline SG0904-15 & Phosphorite & 1.04 & 0.34 & 679.00 & 119.00 & 1.07 & 30.90 & 76.80 & 0.92 & 60.60 & 0.50 & 0.91 \\
\hline SG0904-17 & $\begin{array}{c}\text { Carbonaceous } \\
\text { shale }\end{array}$ & 1.24 & 0.11 & 4181.00 & 589.00 & 4.08 & 85.60 & 68.90 & 5.68 & 29.20 & 5.32 & 1.15 \\
\hline SG0904-19 & $\begin{array}{c}\text { Carbonaceous } \\
\text { shale }\end{array}$ & 1.50 & 0.77 & 5571.00 & 693.00 & 2.70 & 36.30 & 39.60 & 4.90 & 89.30 & 4.41 & 0.66 \\
\hline SG0904-20 & $\begin{array}{c}\text { Carbonaceous } \\
\text { shale }\end{array}$ & 1.51 & 0.48 & 2749.00 & 372.00 & 2.33 & 56.00 & 58.80 & 5.84 & 47.70 & 4.81 & 2.79 \\
\hline SG0904-21 & $\begin{array}{c}\text { Carbonaceous } \\
\text { shale }\end{array}$ & 2.06 & I & 314.00 & 143.00 & 5.07 & 91.50 & 20.10 & 4.34 & 34.60 & 6.23 & I \\
\hline SG0904-2 & Phosphorite & 0.20 & 7.37 & 2.02 & 0.05 & 0.21 & 1.97 & 23.84 & 113.07 & 27.05 & SG0904-2 & Phosphorite \\
\hline SG0904-3 & $\begin{array}{c}\text { Phosphorous } \\
\text { chert }\end{array}$ & 0.30 & 3.10 & 2.21 & 0.04 & 0.61 & 1.98 & 54.64 & 89.24 & 45.14 & SG0904-3 & $\begin{array}{c}\text { Phosphorous } \\
\text { chert }\end{array}$ \\
\hline SG0904-4 & Chert & 0.35 & 11.63 & 4.14 & 0.03 & 2.05 & 1.98 & 108.04 & 52.79 & 61.89 & SG0904-4 & Chert \\
\hline SG0904-5 & Phosphorite & 0.40 & 14.44 & 3.82 & 0.07 & 0.52 & 1.96 & 46.33 & 88.98 & 71.46 & SG0904-5 & Phosphorite \\
\hline SG0904-6 & $\begin{array}{c}\text { Phosphorous } \\
\text { chert }\end{array}$ & 0.46 & 10.82 & 4.18 & 0.06 & 6.33 & 1.96 & 266.16 & 42.06 & 98.80 & SG0904-6 & $\begin{array}{c}\text { Phosphorous } \\
\text { chert }\end{array}$ \\
\hline SG0904-7 & Phosphorite & 0.50 & 8.13 & 3.13 & 0.07 & 1.26 & 1.96 & 144.33 & 114.35 & 92.15 & SG0904-7 & Phosphorite \\
\hline SG0904-9 & Phosphorite & 0.60 & 8.35 & 4.22 & 0.01 & 0.49 & 1.99 & 191.87 & 391.99 & 159.89 & SG0904-9 & Phosphorite \\
\hline SG0904-11 & $\begin{array}{c}\text { Phosphorous } \\
\text { chert }\end{array}$ & 0.75 & 4.36 & 1.73 & 0.42 & 1.09 & 1.76 & 6.22 & 5.73 & 33.12 & SG0904-11 & $\begin{array}{c}\text { Phosphorous } \\
\text { chert }\end{array}$ \\
\hline SG0904-12 & Chert & 0.80 & 2.71 & 2.35 & 0.03 & 5.03 & 1.98 & 242.29 & 48.20 & 57.48 & SG0904-12 & Chert \\
\hline SG0904-14 & Phosphorite & 0.97 & 25.97 & 4.76 & 0.02 & 2.18 & 1.99 & 438.46 & 201.07 & 59.32 & SG0904-14 & Phosphorite \\
\hline SG0904-15 & Phosphorite & 1.04 & 28.88 & 5.71 & 0.02 & 1.27 & 1.99 & 315.07 & 248.61 & 84.41 & SG0904-15 & Phosphorite \\
\hline SG0904-17 & $\begin{array}{c}\text { Carbonaceous } \\
\text { shale }\end{array}$ & 1.24 & 20.98 & 7.10 & 0.19 & 2.36 & 1.88 & 26.72 & 11.32 & 49.13 & SG0904-17 & $\begin{array}{c}\text { Carbonaceous } \\
\text { shale }\end{array}$ \\
\hline SG0904-19 & $\begin{array}{c}\text { Carbonaceous } \\
\text { shale }\end{array}$ & 1.50 & 13.44 & 8.04 & 0.05 & 0.44 & 1.96 & 18.53 & 41.78 & 78.99 & SG0904-19 & $\begin{array}{c}\text { Carbonaceous } \\
\text { shale }\end{array}$ \\
\hline SG0904-20 & $\begin{array}{c}\text { Carbonaceous } \\
\text { shale }\end{array}$ & 1.51 & 24.03 & 7.39 & 0.12 & 1.23 & 1.92 & 25.24 & 20.47 & 35.76 & SG0904-20 & $\begin{array}{c}\text { Carbonaceous } \\
\text { shale }\end{array}$ \\
\hline SG0904-21 & $\begin{array}{c}\text { Carbonaceous } \\
\text { shale }\end{array}$ & 2.06 & 18.05 & 2.20 & 0.13 & 0.58 & 1.92 & 6.66 & 11.46 & 3.15 & SG0904-21 & $\begin{array}{c}\text { Carbonaceous } \\
\text { shale }\end{array}$ \\
\hline
\end{tabular}

“" means not measured. 
then comparing these ratios to the normal shale [15] [41]. The data of standard shale are from McLennan et al. (1984) [42]. The EF values of several redox sensitive elements (such as $\mathrm{U}, \mathrm{Mo}$, and $\mathrm{V}$ ) are given in Table 1 . The $\mathrm{Mo}_{\mathrm{EF}}$ values are from 6.22 to 438.46 (average 146.53), $\mathrm{U}_{\mathrm{EF}}$ values are from 5.73 to 1431.41 (average 182.03), and $\mathrm{V}_{\mathrm{EF}}$ values are from 3.15 to 159.89 (average 60.66).

The $\mathrm{V} / \mathrm{Cr}$ ratios range from 0.34 to 5.71 in the chert-phosphorite beds, and from 2.20 to 8.04 in the carbonaceous shale layers; $\mathrm{Ni} / \mathrm{Co}$ ratios are between 2.71 and 28.9 in the chert-phosphorite assemblages and from 13.4 to 24.0 in the carbonaceous shale beds (Table 1$)$. Furthermore, $\delta \mathrm{U}(\delta \mathrm{U}=2 \mathrm{U} \times(\mathrm{U}+\mathrm{Th} / 3))$ values reveal a little more consistency, and are from 1.76 to 2 , indicate anoxic sedimentary conditions [43] [44].

The TOC concentrations in the laminated chert-phosphorite assemble are from $00.7 \%-0.94 \%$, and from $0.66 \%$ to $2.79 \%$ in the carbonaceous shale layer (Table 1).

\subsection{Evaluation of Detrital Input}

Detrital, biogenic, and hydrogenous fractions show three independent concentrations of sediments [45]. Monitoring of the detrital fraction (i.e., crustal) is necessary to assess the enrichment of redox-sensitive elements relative to their detrital component. Th is stable in the water column, and occurs permanently in the insoluble $\mathrm{Th}^{4+}$ states, and largely independent of factors such as source area and grain size [16]. Therefore, it is used in the present study to monitor detrital input [46]. The lack of correlation between Th concentrations and $\mathrm{U}$, and $\mathrm{V}$ ratios suggests no detrital influence on redox-sensitive elements (Figure 3(a), Figure 3(b)).

\section{Discussions}

\subsection{Redox Sensitive Elements Geochemistry}

Trace elements (e.g., Mo, $\mathrm{U}$, and, $\mathrm{V}$ et al.) and their ratios (including $\mathrm{Ni} / \mathrm{Co}$, $\mathrm{V} / \mathrm{Cr}$, and $\delta \mathrm{U}$ ) have been widely used as indicators for paleoredox conditions

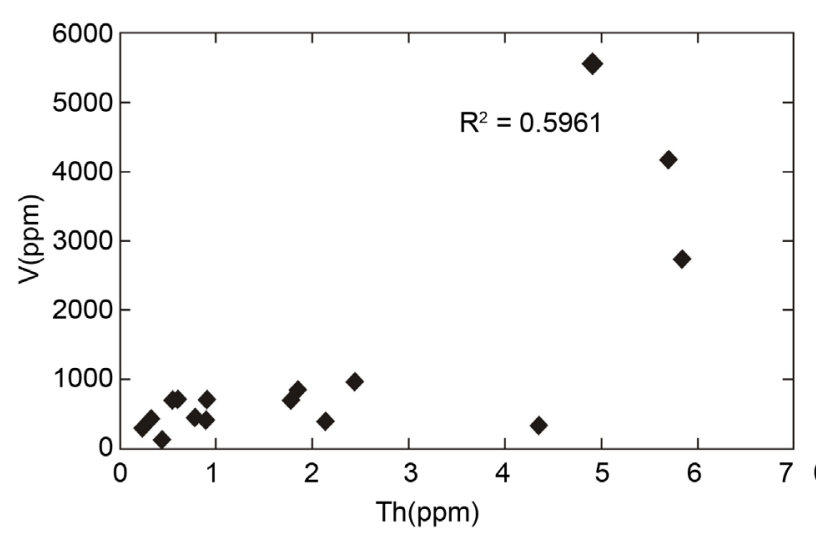

(a)

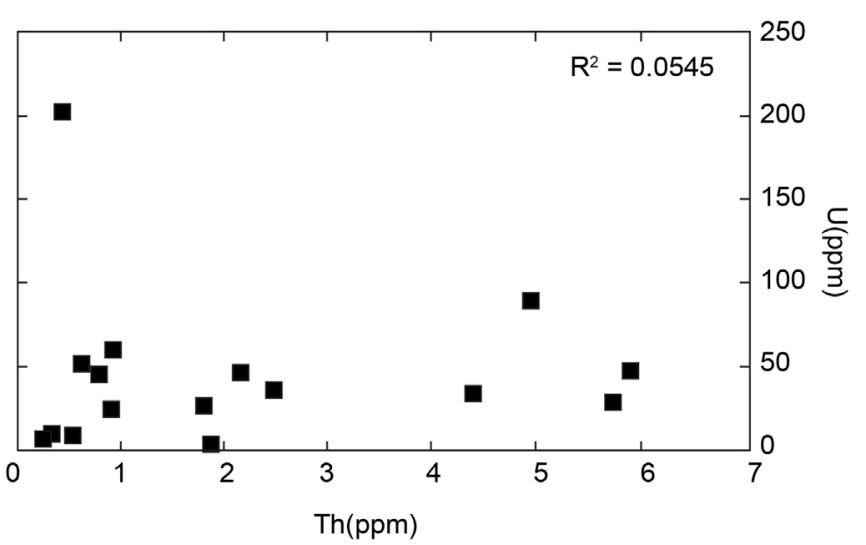

(b)

Figure 3. Cross-plot of various parameters cited from the Yurtus black rock series unit. Th correlates with V (a), and U (b). 
[15] [41] [47] [48]. In anoxic waters, the Mo, U, and V values of the sediments may become highly concentrated, compared to their concentrations in sediments formed under oxygenated water columns [49] [50] [51]. U enrichment is minor in oxic-suboxic environments, where $U$ is present mainly as $U$ (VI) in the form of chemically unreactive uranyl carbonate complex $\left[\mathrm{UO}_{2}\left(\mathrm{CO}_{3}\right)_{3}^{4-}\right]$ [52] [53]. Under anoxic or euxinic conditions, U (VI) can be reduced to U (IV) as the insoluble uranium dioxide $\left(\mathrm{UO}_{2}\right)$ or less soluble uramium fluoride complexes [16] [53] [54]. Just like U, Mo and V is also considered sensitive to conditions around the redox boundary during early diagenesis, and is preferentially enriched in sediments underlying anoxic or euxinic waters [49] [50] [51]. The ratios of $\mathrm{Mo}_{\mathrm{EF}}$ (average 146.53), $\mathrm{V}_{\mathrm{EF}}$ (average 60.66), and $\mathrm{U}_{\mathrm{EF}}$ (average 182.03) $(\mathrm{EF}=$ Enrichment Factor $)$ reveal the relative enrichment than that of average shale, which indicate the sedimentary environment may not be oxygenic environment (Table 2) [49] [50] [51].

Wignall $(1994 \mathrm{a}, \mathrm{b})$ proposed to use the $\delta \mathrm{U}(\delta \mathrm{U}=2 \mathrm{U} \times(\mathrm{U}+\mathrm{Th} / 3))$ index to distinguish the sedimentary environment of shales, with $\delta U>1$ representing anoxic environment and $\delta U<1$ for normal marine sedimentary environment. Based on this criterion, all samples fall into the anoxic region (Table 2) [43] [44]. Therefore, this criterion is not suitable for environment analysis of our data. It needs more rigorous criteria to constrain the sedimentary environment of the black shale series we studied.

Previous studies have established standard values for trace element ratios to distinguish oxic, suboxic and anoxic conditions (Table 2) [9] [15] [41] [54] [55]. Although different redox indicators have diverse threshold to indicate the redox conditions, there is general trend that $\mathrm{V} / \mathrm{Cr}$ and $\mathrm{Ni} / \mathrm{Co}$ ratios increase with decreasing oxygenation levels in water columns [9] [15] [41] [54] [55]. Figure 2 reveals that the samples in the carbonaceous shale beds fall into the suboxicanoxic sedimentary conditions area, and most of chert-phosphorite samples are also deposit in suboxic-anoxic sedimentary conditions. The same patterns could also be observed from Ni/Co vs. Mo and $\mathrm{V} / \mathrm{Cr}, \delta \mathrm{U}$ vs. Ni/Co and $\mathrm{V} / \mathrm{Cr}$ (Figure 4). However, the lithology of the basal Yurtus Formation is kinds of phosphatic rocks, $\mathrm{U}$ enrichment, $\mathrm{V}$ enrichment, and $\mathrm{V} / \mathrm{Cr}$ ratio could not be used as indicators

Table 2. Redox classification of the depositional environment.

\begin{tabular}{|c|c|c|c|c|}
\hline $\begin{array}{l}\text { Sedimentary conditions } \\
\text { Indicator }\end{array}$ & Oxic & Suboxic & Anoxic & Euxinic \\
\hline $\mathrm{H}_{2} \mathrm{~S}$ & & $\begin{array}{l}\text { No free } \mathrm{H}_{2} \mathrm{~S} \text { in the } \\
\text { water column }\end{array}$ & & $\begin{array}{l}\text { Free } \mathrm{H}_{2} \mathrm{~S} \text { present in } \\
\text { the water column }\end{array}$ \\
\hline $\begin{array}{l}\mathrm{O}_{2} \text { concentration in bottom } \\
\text { waters [9] }\left(\mathrm{mLO}_{2} / \mathrm{LH}_{2} \mathrm{O}\right)\end{array}$ & $\mathrm{O}_{2}>2$ & $0.2<\mathrm{O}_{2}<2$ & $\mathrm{O}_{2}<0.2$ & $\mathrm{O}_{2}=0,\left[\mathrm{H}_{2} \mathrm{~S}\right]>11 \mu \mathrm{m}$ \\
\hline$\delta \mathrm{U}[43]$ [44] & $<1$ & $<1$ & & I \\
\hline $\mathrm{V} / \mathrm{Cr}[55]$ & $<2$ & $2-4.25$ & & $>4.25$ \\
\hline $\mathrm{Ni} / \mathrm{Co}[55]$ & $<5$ & $5-7$ & $>7$ & I \\
\hline
\end{tabular}




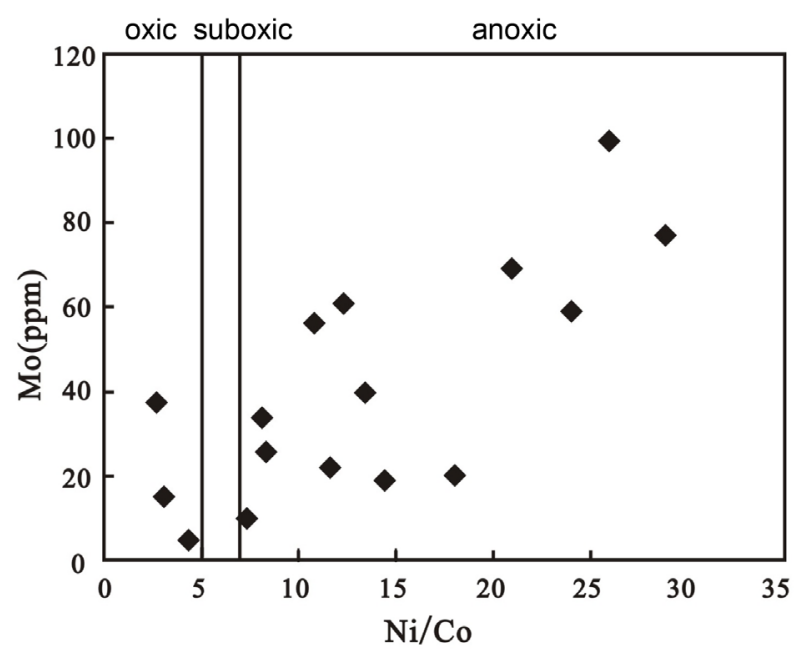

(a)

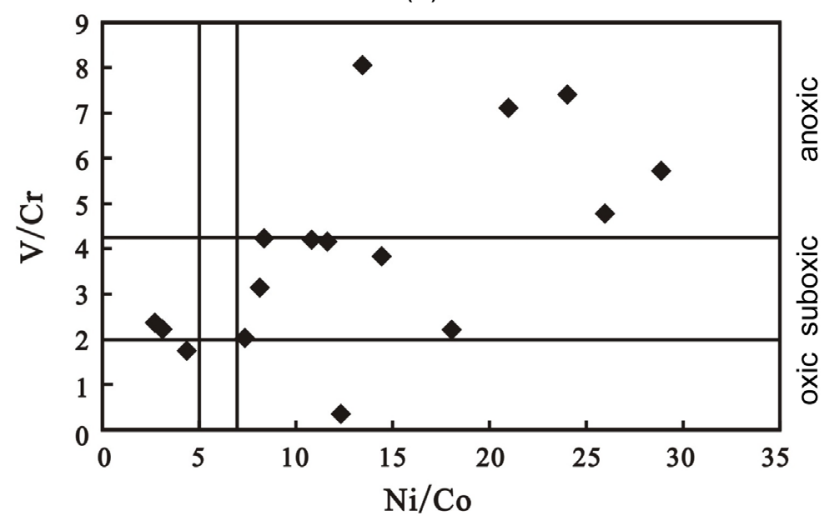

(c)

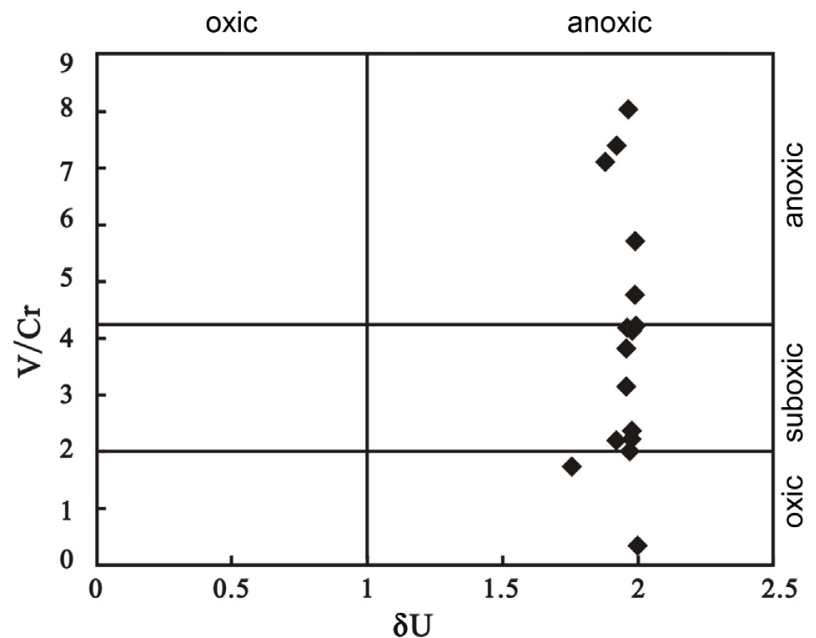

(b)

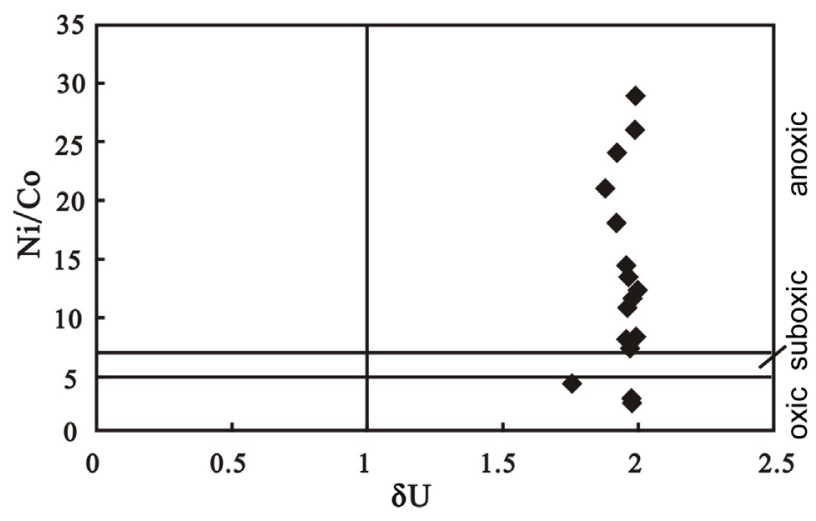

(d)

Figure 4. Crossplots of trace element ratios as paleoredox proxies. (a) Mo vs. Ni/Co; (b) V/Cr vs. $\delta \mathrm{U}$; (c) V/Cr vs. Ni/Co; (d) $\mathrm{Ni} / \mathrm{Co} v$ s. $\delta \mathrm{U}$. Ranges for $\mathrm{Ni} / \mathrm{Co}$ and $\mathrm{V} / \mathrm{Cr}$ are from Jones et al. (1994) [55]; range for $\delta \mathrm{U}$ is from Wignall (1994a, b) [43] [44].

of depositional conditions, due to the disturbance of the system by the substitution of $\mathrm{V}$ and $\mathrm{U}$ into apatite [11].

Phosphorite genesis needs a favorable environment in the bottom water. Upwelling hydrothermal fluid and transgressive events could generate the proper conditions for the formation of phosphate nodules [16]. The REE results indicate that the lower Yurtus Formation shales are highly influenced by hydrothermal inputs [23] [27]. The phosphatic rocks and cherts of the basal Yurtus Formation exhibit oxic conditions with significantly negative Ce anomalies, and $\mathrm{Ce} / \mathrm{Ce}^{\star}$ is in the range of $0.37-0.48$ [27]. These significantly negative Ce anomalies are generally ascribed to organic matter derived from organisms in the euphotic zone [26]. However, the TOC concentrations of phosphatic rock and cherts are relatively low (Table $1,<0.94$ wt \%). Therefore, organic matter may not be the main trace element source for the phosphorites and cherts. The formation of phosphorite, especially phosphate nodules, in siliciclastic depositional systems might be related to high-energy hydrodynamic regimes, reworking and redeposition [56] [57] [58]. In addition, no sulfide was found at basal of the Yurtus Formation in the studied area. Thus, the bottom water during the early 
Cambrian could not be anoxic or euxin. Study on the Liuchapo Formation, southeastern Chongqing proposed by Li et al. (2015) further indicates the oxygen sedimentary conditions in early Cambrian [56] These consistent results from different areas demonstrate that oxic bottom seawater widespread in the whole basin around the Ediacaran-Cambrian boundary, and the following transgressive event induced an anoxic basin at the beginning of the early Cambrian.

\subsection{Mo Isotopic Geochemistry}

Mo isotope fractionation patterns have been used to reconstruct the redox state of the Earth's atmosphere and oceans [4] [7]. The $\delta^{88 / 95}$ Mo isotope composition of the black rock series from the Sugtebrak section, is from $-0.17 \%$ o to $1.56 \%$, and reveal two negative anomalies ( $\mathrm{N} 1$ and $\mathrm{N} 2)$ and one positive recovery (P1) over a few meters of stratigraphy thickness only (Figure 2, Table 1). Several mechanisms could contribute to the variabilities of Mo fraction, including: 1) the changes of the redox conditions (such as oxic, anoxic and strongly euxinic water-column). In oxygenated seawater, $\mathrm{Mo}$ is present as $\mathrm{MoO}_{4}^{2-}$, and Mo isotope signature has light Mo isotopic composition $\left(\delta^{88 / 95} \mathrm{Mo}=-0.7 \%\right.$ ) , which represent a large $(\sim 3 \%)$ negative fractionation relative to the modern seawater composition $\left(\delta^{88 / 95} \mathrm{Mo}_{\text {sw }}\right.$ ) of $\sim+2.3 \%$ [59] [60] [61]. A growing realization that Mo isotopes could also be fractionated during removal in intermediate redox environment where $\mathrm{O}_{2}$ is scarce but $\mathrm{H}_{2} \mathrm{~S}$ is not abundant which is so-called suboxic or anoxic setting [14]; 2) low-temperature hydrothermal systems. Mo may have been fractionated by precipitation of hydrothermal Fe-Mn oxides [5] [62] [63] [64]; and 3) influx of riverine Mo in restricted ocean basins not fully connected to the global ocean circulation.

In the Sugtbrak section, the $\delta^{98 / 95}$ Mo ratios show lighter than that present-day euxinic sediments (2.3\%o) [61], and heavier than typical of Mo adsorbed onto Mn oxides (-0.7\%o) [61] [65], and fall into the range of suboxic sediments (Figure 5). The pattern of $\delta^{98 / 95} \mathrm{Mo}$ curve has good relationships with trace element ratios $\left(\mathrm{V} / \mathrm{Cr}\right.$ and $\mathrm{Ni} / \mathrm{Co}$ ) trends (Figure 2). $\delta^{98 / 95} \mathrm{Mo}$ negative anomaly (N1 and N2) could correspond to the suboxic-anxoic conditions which $\mathrm{V} / \mathrm{Cr}$ and $\mathrm{Ni} / \mathrm{Co}$ ratios indicated, and the $8^{88 / 95} \mathrm{Mo}$ positive shift (P1, Figure 2) also could relative with the oxic-suboxic conditions. Wen et al. (2015) reported $\delta^{88 / 95} \mathrm{Mo}$ values of early Cambrian black shales, which have a wide range of $\delta^{88 / 95}$ Mo values $(0.27 \%$ - $1.79 \%$ o $)$ in carbonaceous shales and cherts (interval 1$)$, and are from $0.11 \%$ o to $1.70 \%$ in black shale layer (interval 2) in the Zunyi section, in South China [7]. Combining with Fe abundance in samples, redox elements characters, and $\delta^{88 / 95}$ Mo values, the redox conditions changed from anoxic and ferruginous in interval 1, and euxinic in interval 2 have been concluded [7]. Comparison with Zunyi section, no sulfide layer was occurred in the Sugetbrak section during the early Cambrian period. At the same time, the Early Cambrian sediments were affected by upwelling oceanic hydrothermal fluids [23] [27]. So the variation of Mo isotope in this study might not be merely connected with the suboxic or anoxic paleo-environment. 


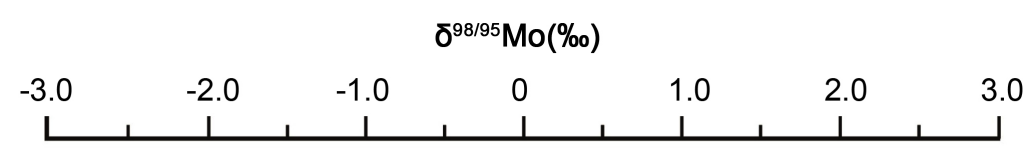

(a) OXIC(Mn oxides)

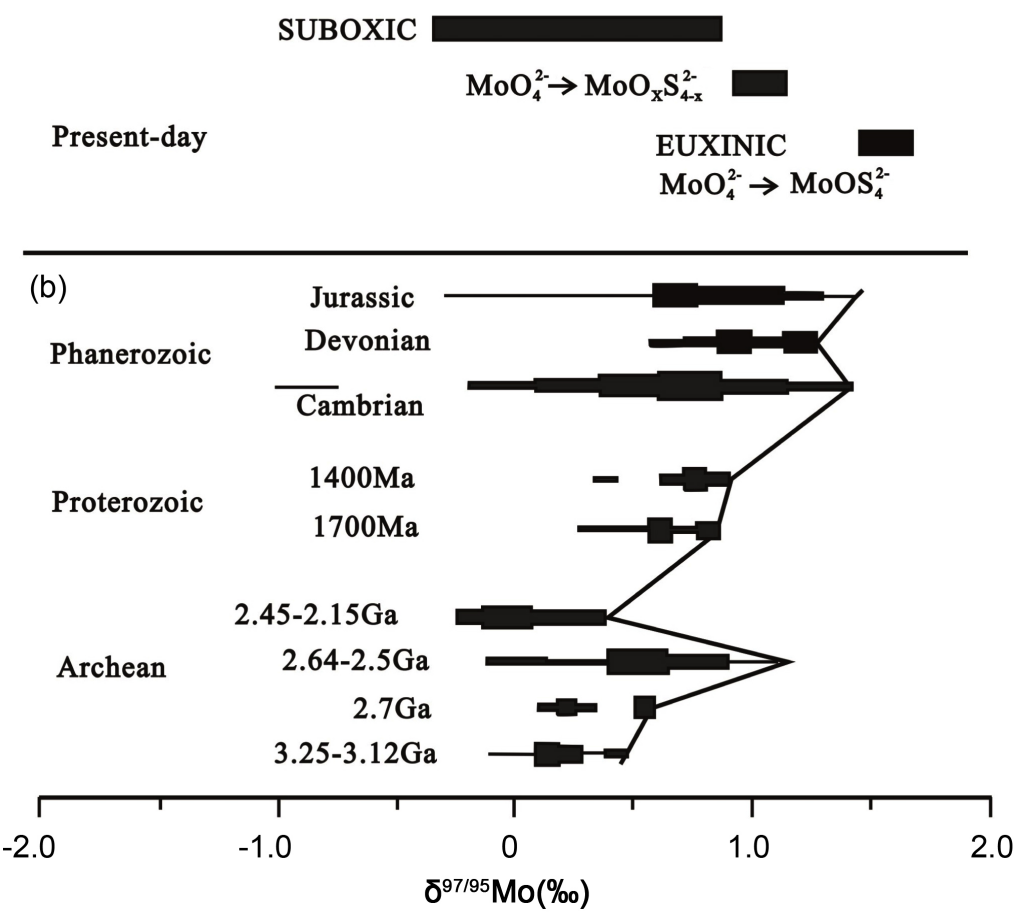

Figure 5. Mo isotope composition of present-day seawater sources and variations of reducing sediment in Earth history [5] [61].

Overprint by fractioned Mo from low-temperature hydrothermal systems onto sediments could also result in the variabilities of Mo isotope composition [62] [63]. REE and Os isotope of the black shales give the clues of the hydrothermal overprint [23] [27], indicating that the hydrothermal fluid might affect the variability of Mo isotope and the Mo enrichment in our study. At the end of Neoproterozoic, the southern Tianshan Ocean began to pull-apart because of the breakup of the Rodinia suppercontinent [23] [66]. The northern Tarim passive continental margin and southern Tianshan Ocean were developed in the Cambrian [66]. There are no deep faults developed on the northern Tarim passive continental shelf and no possibility to form local hydrothermal activity. The hydrothermal fluid in the northern Tarim continental shelf might come from extensional setting during the pattern of transgression and a rapid regional sealevel rise in the early Cambrian [23].

Kirschvink et al. (1997) argued that marine circulation was reorganized repeatedly during the early Cambrian [67]. Nevertheless, the regional restricted basin with occasional seawater replenishment and intermittent dominance by continental input into restricted basins via riverine transport was preferred in our study. Mo contents of black rock series are generally within dozens of ppm range (Table 1), similar to black shales of the Niutitang Formation (a strati- 
graphic equivalent of the Yuetus Formation) from the Dingtai profile investigated by $\mathrm{Xu}$ et al. (2012), who argued that the Dingtai profile represents a restricted basinal environment [5]. At the same time, geophysics, geochemistry, and stratigraphic characters also support that the Tarim Basin is a kind of regional restricted basin with passive continental margin during the early Cambrian period [23] [27] [68]. The remarkable variability of $8^{8895}$ Mo composition in the black rock series could be the expression the interplay between open seawater and continental input into restricted basins via riverine transport [59]. In the restricted basin, Mo influx is dominated by continental input, and is replenished by new seawater with heavy Mo restores the normal seawater situation [5]. The comparatively large number of samples with $\delta^{98 / 95} \mathrm{Mo}$ below average present-day dissolved river load $(0.7 \%$ ) [69], and belong to the characters of continental margin suboxic sediments (from $-0.7 \%$ to $1.6 \%$ ) [59].

\subsection{Oceanic Sedimentary Environment during the Early Cambrian of the Tarim Basin}

There is a long standing debate about the reason for significant changes in oceanic geochemistry during the Ediacran-Cambrian transition [26] [29] [30] [70] [71]. Our study researches the redox sensitive elements, TOC, and Mo isotope characters of the black rock series (cherts-phosphorite assemblages and carbonaceous shale) to evaluate the changes of sedimentary condition during the early Cambrian in the Tarim Basin. A schematic model of the depositional environment of the black rock series is shown in Figure 6. The sedimentary condition where black rock series deposited was the restricted basin and near the continental margin. And the $\delta^{88 / 95}$ Mo values also reveal the characters of continental

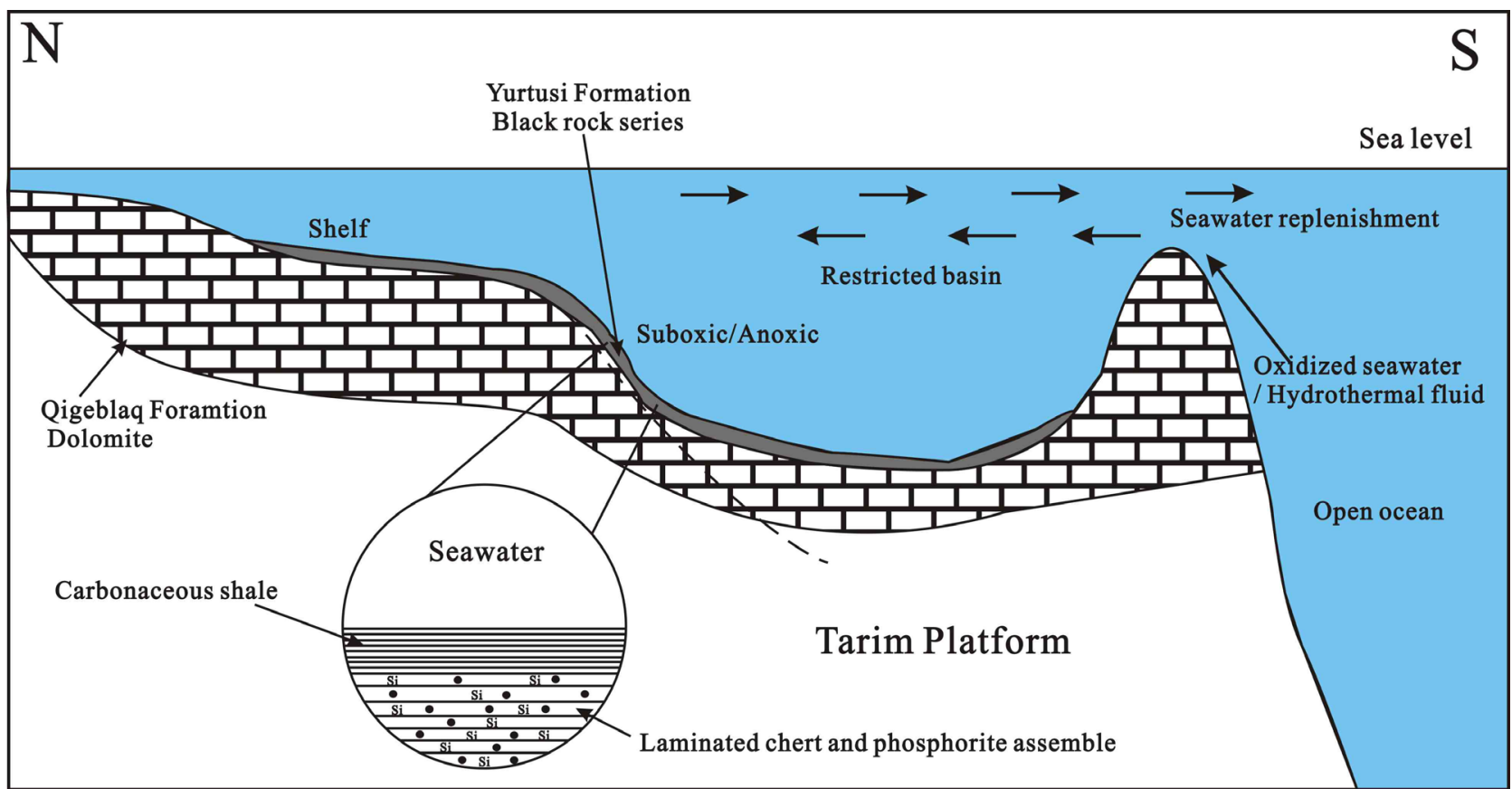

Figure 6. The schematic model of deposition environment for the black rock series. 
margin suboxic sediments (from $-0.7 \%$ o to $1.6 \%$ ) [59].

At the beginning of the early Cambrian (Nemakit-Daldynian age), the black rock series was drowned by a transgressive event [33]. And the sea level stayed a relative low level with the first episode hydrothermal fluid. Oxic seawater conditions in combination with nutrition provided by upwelling hydrothermal fluids induced the formation of phosphorite. Trace element and Mo isotope data suggest that interbedded chert-phosphorite assembles were scavenged from seawater under restricted conditions. The inferred scavenging process could occurred under replenishment of nutrition to the restricted basins by upwelling oxidize seawater [25] [72]. High current or wave energy in combination with oxic seawater did not favor the preservation of organic matter, thus, the TOC contents of the basal Yurtus Formation are quiet low $(0.05 \%-0.94 \%)$ in cherts-phosphorite assemblages layer. When the relatively sea level increase, the early Cambrian shallow sea became lack oxygen and become suboxic/anoxic. In the suboxic/anoxic conditions of the bottom water, the organic matter that fell from the photic zone partly oxidized because the residual oxygen in the seafloor. Thus, the TOC concentrations of upper Yurtus Formation carbonaceous shale are low $(1.15 \%-2.79 \%)$. In combination with the suboxic/anoxic conditions, another episode of hydrothermal activities promoted the enrichment of trace elements.

\section{Conclusions}

Combination with previously report data and the analysis of the geochemical redox indicators, TOC concentration, and Mo isotope data from black rock series at early Cambrian in the Tarim Basin, we conclude the following:

1) During the early Cambrian period, the transgressive and upwelling hydrothermal fluids from the open ocean have taken lots of nutritions into the restricted basin. Oxic conditions and rich nutritious water induced the laminated chert-phosphorite sedimentary with low TOC concentrations. When the sea level continues to rise, the sedimentary conditions of bottom water became relative lack oxygen, where were fit for the sedimentary of the carbonaceous shale in the restricted basin.

2) The Mo isotope compositions of black rock series could not only affected by hydrothermal events, but also the changes of sea level, and marine conditions.

\section{Acknowledgements}

We are very grateful to the reviewers for their reviews and suggestions, which significantly improved the quality of the manuscript. This work was supported by National Natural Science Foundation of China (No. 41203023).

\section{References}

[1] Algeo, T.J. and Maynard, J.B. (2004) Trace-Element Behavior and Redox Facies in Core Shales of Upper Pennsylvanian Kansas-Type Cyclothems. Chemical Geology, 206, 289-318. https://doi.org/10.1016/j.chemgeo.2003.12.009

[2] Arnold, G.L., Anbar, A.D., Barling, J. and Lyons, T.W. (2004) Molybdenum Isotope 
Evidence for Widespread Anoxia in Mid-Proterozoic Oceans. Science, 304, 87-90. https://doi.org/10.1126/science.1091785

[3] Pearce, C.R., Cohen, A.S., Coe, A.L. and Burton, K.W. (2008) Molybdenum Isotope Evidence for Global Ocean Anoxia Coupled with Perturbations to the Carbon Cycle during the Early Jurassic. Geology, 36, 231-234. https://doi.org/10.1130/G24446A.1

[4] Kendall, B., Gordon, G.W., Poulton, S.W. and Anbar, A.D. (2011) Molybdenum Isotope Constraints on the Extent of Late Paleoproterozoic Ocean Euxinia. Earth and Planetary Science Letters, 307, 450-460.

https://doi.org/10.1016/j.epsl.2011.05.019

[5] Xu, L.G., Lehmann, B., Mao, J.W., Nägler, T.F. and Neubert, N. (2012) Mo Isotope and Trace Element Patterns of Lower Cambrian Black Shales in South China: Multi-Proxy Constraints on the Paleoenvironment. Chemical Geology, 318-319, 45-59. https://doi.org/10.1016/j.chemgeo.2012.05.016

[6] Herrmann, A.D., Kendall, B., Algeo, T.J. and Gordon, G.W. (2012) Anomalous Molybdenum Isotope Trends in Upper Pennsylvanian Euxinic Facies: Significance for Use of $\delta^{98}$ Mo as a Global Marine Redox Proxy. Chemical Geology, 324-325, 87-98. https://doi.org/10.1016/j.chemgeo.2012.05.013

[7] Wen, H.J., Fan, H.F., Zhang, Y.X., Cloquet, C. and Carignan, J. (2015) Reconstruction of Early Cambrian Ocean Chemistry from Mo Isotopes. Geochimica et Cosmochimica Acta, 164, 1-16. https://doi.org/10.1016/j.gca.2015.05.008

[8] Wignall, P.B. and Myers, K.J. (1988) Interpreting Benthic Oxygen Levels in Mud Rocks: A New Approach. Geology, 16, 452-455. https://doi.org/10.1130/0091-7613(1988)016<0452:IBOLIM>2.3.CO;2

[9] Tyson, R.V. and Pearson, T.H. (1991) Modern and Ancient Continental Shelf Anoxia: An Overview. In: Tyson, R.V. and Pearson, T.H., Eds., Modern and Ancient Continental Shelf Anoxia, Geological Society Specical Publications, London, 1-24. https://doi.org/10.1144/GSL.SP.1991.058.01.01

[10] Scott, C. and Lyons, T.W. (2012) Contrasting Molybdenum Cycling and Isotopic Properties in Euxinic versus Non-Euxinic Sediments and Sedimentary Rocks: Refining the Paleoproxies. Chemistry Geology, 324-325, 19-27.

https://doi.org/10.1016/j.chemgeo.2012.05.012

[11] Neubert, N., Nägler, T.F. and Böttcher, M.E. (2008) Sulphidity Controls Molybdenum Isotope Fractionation into Euxinic Sediments: Evidence from the Modern Black Sea. Geology, 36, 775-778. https://doi.org/10.1130/G24959A.1

[12] Helz, G.R., Miller, C.V., Charnock, J.M., Mosslemans, J.F.W., Pattrick, R.A.D., Garner, C.D. and Vaughan, D.J. (1996) Mechanism of Molybdenumremoval from the Sea and Its Concentration in Black Shales: EXAFS Evidence. Geochimica et Cosmochimica Acta, 60, 3631-3642. https://doi.org/10.1016/0016-7037(96)00195-0

[13] Zheng, Y., Anderson, R.F., Van, G.A. and Kuwabara, J. (2000) Authigenic Molybdenum Formation in Marine Sediments: A Link to Pore Water Sulfide in the Santa Barbara Basin. Geochimica et Cosmochimica Acta, 64, 4165-4178. https://doi.org/10.1016/S0016-7037(00)00495-6

[14] Anbar, A.D. (2004) Molybdenum Stable Isotopes: Observations, Interpretations and Directions. Reviews in Mineralogy and Geochemistry, 55, 429-454. https://doi.org/10.2138/gsrmg.55.1.429

[15] Rimmer, S.M. (2004) Geochemical Paleoredox Indicators in Devonian-Mississippian Black Shales, Central Appalachian Basin (USA). Chemistry Geology, 206, 373 391. https://doi.org/10.1016/j.chemgeo.2003.12.029

[16] Tribovillard, N., Algeo, T.J. and Lyons, T. (2006) Trace Metals as Paleoredox and 
Paleoproductivity Proxies: An Update. Chemistry Geology, 232, 12-32. https://doi.org/10.1016/j.chemgeo.2006.02.012

[17] Pattan, J.N. and Pearce, N.J.G. (2009) Bottom Water Oxygenation History in Southeastern Arabian Sea during the Past 140 ka: Results from Redox-Sensitive Elements. Palaeogeography Palaeoclimatology Palaeoecology, 280, 396-405. https://doi.org/10.1016/j.palaeo.2009.06.027

[18] Brasier, M.D. (1992) Background to the Cambrian Explosion. Journal of the Geological Society, 149, 585-587. https://doi.org/10.1144/gsjgs.149.4.0585

[19] Shu, D.G., Morris, S.C., Han, J., Chen, L., Zhang, X.L., Liu, H.Q., Li, Y. and Liu, J.N. (2001) Primitive Deuterostomes from the Chengjiang Lagerstatte (Lower Cambrian, China). Nature, 414, 419-424. https://doi.org/10.1038/35106514

[20] Banerjee, D.M., Schidlowski, M., Siebert, F. and Brasier, M.D. (1997) Geochemical Changes across the Proterozoic-Cambrian transition in the Durmala Phosphoritemine Section, Mussoorie Hills, Garhwal Himalaya, India. Palaeogeography Palaeoclimatology Palaeoecology, 132, 183-194. https://doi.org/10.1016/S0031-0182(97)00060-6

[21] Kimura, H. and Watanabe, Y. (2001) Oceanic Anoxia at the Precambrian-Cambrian Boundary. Geology, 29, 995-998. https://doi.org/10.1130/0091-7613(2001)029<0995:OAATPC>2.0.CO;2

[22] Orberger, B., Pasava, J., Paul Gallien. J., Daudin, L. and Trocellier, P. (2003) Se, As, Mo, Ag, Cd, In, Sb, Pt, Au, Tl, Re Traces in Biogenic and Abiogenic Sulfides from Black Shales (Selwyn Basin, Yukon Territories, Canada): A Nuclear Microprobe Study. Nuclear Instruments and Methods in Physics Research, Section B, 210, 441448.

[23] Yu, B.S., Dong, H.L. and Widom, E. (2009) Geochemistry of Basal Cambrian Black Shales and Cherts from the Northern Tarim Basin, Northwest China: Implications for Depostional Setting and Tectonic History. Journal of Asian Earth Science, 34, 418-436. https://doi.org/10.1016/j.jseaes.2008.07.003

[24] Li, D., Ling, H.F., Shields-Zhou, G.A., Chen, X., Cremonese, L., Och, L., Thirlwall, M. and Manning, C.J. (2013) Carbon and Strontium Isotope Evolution of Seawater across the Ediacaran-Cambrian Transition: Evidence from the Xiaotan Section, NE Yunnan, South China. Precambrian Research, 225, 128-147. https://doi.org/10.1016/j.precamres.2012.01.002

[25] Mao, J., Lehmann, B., Du, A., Zhang, G., Ma, D., Wang, Y., Zeng, M. and Kerrich, R. (2002) Re-Os Dating of Polymetallic Ni-Mo-PGE-Au Mineralization in Lower Cambrian Black Shales of South China and Its Geologic Significance. Economic Geology, 97, 1051-1061. https://doi.org/10.2113/gsecongeo.97.5.1051

[26] Pi, D.H., Liu, C.Q., Shields-Zhou, A. and Jiang, S.Y. (2013) Trace and Rare Earth Element Geochemistry of Black Shale and Kerogen in the Early Cambrian Niutitang Formation in Guizhou Province, South China: Constraints for Redox Environments and Origin of Metal Enrichments. Precambrian Research, 225, 218-229. https://doi.org/10.1016/j.precamres.2011.07.004

[27] Yao, C.Y., Ma, D.S., Ding, H.F., Zhang, X.Y. and Huang, H. (2014) Trace Elements and Stable Isotopic Geochemistry of an Early Cambrian Chert-Phosphorite Unit from the Lower Yurtus Formation of the Sugetbrak Section in the Tarim Basin. Science China Earth Sciences, 57, 454-464. https://doi.org/10.1007/s11430-013-4760-9

[28] Zhou, C.M. and Jiang, S.Y. (2009) Palaeoceanographic Redox Environments for the Lower Cambrian Hetang Formation in South China: Evidence from Pyrite Fram- 
boids, Redox Sensitive Trace Elements, and Sponge Biota Occurrence. Palaeogeography Palaeoclimatology Palaeoecology, 271, 279-286.

https://doi.org/10.1016/j.palaeo.2008.10.024

[29] Jiang, S.Y., Chen, Y.Q., Ling, H.F., Yang, J.H., Feng, H.Z. and Ni, P. (2006) Traceand Rare-Earth Element Geochemistry and $\mathrm{Pb}-\mathrm{Pb}$ Dating of Black Shales and Intercalated Ni-Mo-PGE-Au Sulfide Ores in Lower Cambrian Strata, Yangtze Platform, South China. Mineralium Deposita, 41, 453-467. https://doi.org/10.1007/s00126-006-0066-6

[30] Jiang, S.Y., Yang, J.H., Ling, H.F., Chen, Y.Q., Feng, H.Z., Zhao, K.D. and Ni, P. (2007) Extreme Enrichment of Polymetallic Ni-Mo-PGE-Au in Lower Cambrian Black Shales of South China: an Os Isotope and PGE Geochemical Investigation. Palaeogeography, Palaeoclimatology, Palaeoecology, 254, 217-228. https://doi.org/10.1016/j.palaeo.2007.03.024

[31] Och, L.M., Shields-Zhou, G.A., Poulton, S.W., Manning, C., Thirlwall, M.F., Li, D., Chen, X., Ling, H.F. and Osborn, T. (2013) Redox Changes in Early Cambrian Black Shales at Xiaotan Section, Yunnan Province, South China. Precambrian Research, 225, 166-189. https://doi.org/10.1016/j.precamres.2011.10.005

[32] Zhang, C. L., Zou, H.B., Santosh, M., Ye, X.T. and Li, H.K. (2014) Is the Precambrian Basement of the Tarim Craton in NW China Composed of Discrete Terranes? Precambrian Research, 254, 226-244. https://doi.org/10.1016/j.precamres.2014.08.006

[33] Wang, W.Y., Xiao, B. and Zhang, S.S. (1985) The Distribution and Correlation of the Cambrian in the Aksu-Wushi Area in Xijian. Xinjiang Geology, 3, 59-73. (In Chinese)

[34] Yu, B.S., Wang, L.D. and Chen, J.Q. (2003) The Suboxic Depositional Setting of Black Shales in Lower Cambrian from Northern Tarim Basin. Earth Science Froniter, 10, 545-550. (In Chinese)

[35] Yao, J.X., Xiao, S.H. and Yin, L.M. (2005) Basal Cambrian Microfossils from the Yurtus and Xishanblaq Formations (Tarim, North-West China): Systematic Revision and Biostratigraphic Correlation of Micrhystridiumlink Acritatchs from China. Palaeontology, 48, 1-23. https://doi.org/10.1111/j.1475-4983.2005.00484.x

[36] Bureau of Geology and Mineral Resources of Xinjiang Uygur Autonomous Region (1982) Regional Geology of Xinjiang Uygur Autonomous Region. Geology Publishing House, Beijing, 1-841. (In Chinese)

[37] Qian, Y., Yin, G.Z. and Xiao, B. (2000) Opercula of Hyoliths and Operculum-Like Fossils from the Lower Cambrian Yuertusi Formation, Xinjiang. Acta Micropalaeontol, 17, 404-415. (In Chinese)

[38] Zhang, Y.X., Wen, H.J. and Fan, H.F. (2009) Chemical Pretreatment Methods for Measurement of Mo Isotope Ratio on Geological Samples. Chinese Journal Anal Chemistry, 37, 216-220.

[39] Wen, H.J., Carignan, J., Cloquet, C., Zhu, X.K. and Zhang, Y.X. (2010) Isotopic Delta Values of Molybdenum Standard Reference and Prepared Solutions Measured by MC-ICP-MS: Proposition for Delta Zero and Secondary References. Journal of Analytical Atomic Spectrometry, 25, 716-721. https://doi.org/10.1039/b921060a

[40] Wen, H.J., Carignan, J., Zhang, Y.X., Fan, H.F., Cloquet, C. and Liu, S.R. (2011) Molybdenum Isotopic Records across the Ediacaran Cambrian Boundary. Geology, 39, 775-778. https://doi.org/10.1130/G32055.1

[41] Wang, S.F., Zou, C.N., Dong, D.Z., Wang, Y.M., Li, X.J., Huang, J.L. and Guan, Q.Z. (2015) Multiple Controls on the Paleoenvironment of the Early Cambrian Marin 
Black Shales in the Sicuhan Basin, SW China: Geochemical and Organic Carbon Isotopic Evidence. Marine and Petroleum Geology, 66, 660-672. https://doi.org/10.1016/j.marpetgeo.2015.07.009

[42] McLennan, S.M., Taylor, S.R. and McGregor, V.R. (1984) Geochemistry of Archean Metasedimentary Rocks from West Greenland. Geochimica et Cosmochimica Acta, 48, 1-13. https://doi.org/10.1016/0016-7037(84)90345-4

[43] Wignall , P.B. (1994a) Black Shales. Clarendon Press, Oxford.

[44] Wignall, P.B. (1994b) Black Shales. Clarendon Press, Oxford, 1e46.

[45] Piper, D.Z. (1994) Seawater as the Source of Minor Elements in Black Shales, Phosphorite and Other Sedimentary Rocks. Chemistry Geology, 114, 95-114. https://doi.org/10.1016/0009-2541(94)90044-2

[46] Taylor, S.R. and Mclennan, S.M. (1985) The Continental Crust: Its Composition and Evolution. Blackwell Scientific Publications, London, 57-72.

[47] Hatch, J.R. and Leventhal, J.S. (1992) Relationship between Inferred Redox Potential of the Depositional Environment and Geochemistry of the Upper Pennsylvanian (Missourian) Stark Shale Member of the Dennis Limestone, Wabaunsee County, Kansa, USA. Chemical Geology, 99, 65-82. https://doi.org/10.1016/0009-2541(92)90031-Y

[48] Morford, J.L. and Emerson, S. (1999) The Geochemistry of Redox Sensitive Trace Metals in Sediments. Geochimica et Cosmochimica Acta, 63, 1735-1750. https://doi.org/10.1016/S0016-7037(99)00126-X

[49] Calvert, S.E. and Pedersen, T.F. (1993) Geochemistry of Recent Oxic and Anoxic Sediments: Implications for the Geological Record. Marine Geology, 113, 67-88. https://doi.org/10.1016/0025-3227(93)90150-T

[50] Wignall, P.B., Zonneveld, J.P., Newton, R.J., Amor, K., Sephton, M.A. and Hartley, S. (2007) The End-Triassic Mass Extinction Record of Williston Lake, British Columbia. Palaeogeography, Palaeoclimatology, Palaeoecology, 253, 385-406. https://doi.org/10.1016/j.palaeo.2007.06.020

[51] Zhou, L., Wignall, P.B., Su, J., Feng, Q.L., Xie, S.C., Zhao, L.S. and Huang, J.H. (2012) U/Mo Ratios and $\delta^{88 / 95} \mathrm{Mo}$ as Local and Global Redox Proxies during Mass Extinction Events. Chemical Geology, 324-325, 99-107. https://doi.org/10.1016/j.chemgeo.2012.03.020

[52] Langmuir, D. (1978) Uranium Solution-Mineral Equilibria at Low Temperatures with Applications to Sedimentary Ore Deposits. Geochimica et Cosmochimica Acta, 42, 547-569. https://doi.org/10.1016/0016-7037(78)90001-7

[53] Algeo, T.J. and Tribovillard, N. (2009) Environmental Analysis of Paleoceanographic Systems Based on Molybdenum-Uranium Covariation. Chemical Geology, 268, 211-225. https://doi.org/10.1016/j.chemgeo.2009.09.001

[54] Wignall, P.B. and Twitchett, R.J. (1996) Oceanic Anoxia and the End Permian Mass Extinction. Science, 272, 1155-1158. https://doi.org/10.1126/science.272.5265.1155

[55] Jones, B.J. and Manning, A.C. (1994) Comparison of Geochemical Indices Used for the Interpretation of Palaeo-Redox Conditions in Ancient Mudstones. PALAEO, 111, 111-129.

[56] Li, Y.F., Fan, T.L., Zhang, J.C., Zhang, J.P., Wei, X.J., Hu, X.L., Zeng, W.T. and Fu, W. (2015) Geochemical Changes in the Early Cambrian Interval of the Yangtze Platform, South China: Implications for Hydrothermal Influences and Paleocean Redox Conditions. Journal of Asian Earth Sciences, 109, 100-123. https://doi.org/10.1016/j.jseaes.2015.05.003 
[57] Trappe, J. (1998) Phanerozoic Phosphorite Depositional System: A Dynamic Model for a Sedimentary Resource System. Springer, Berlin, New York. https://doi.org/10.1007/BFb0009670

[58] Follmi, K.B. (1996) The Phosphorus Cycle, Phosphogenesis and Marine PhosphateRich Deposits. Earth-Science Reviews, 40, 55-124. https://doi.org/10.1016/0012-8252(95)00049-6

[59] Siebert, C., McManus, J., Bice, A., Poulson, R. and Berelson, W.M. (2006) Molybdenum Isotope Signatures in Continental Margin Marine Sediments. Earth and Planetary Science Letters, 241, 723-733. https://doi.org/10.1016/j.epsl.2005.11.010

[60] Poulson, R.L., McManus, J., Severmann, S. and Berelson, W.M. (2009) Molybdenum Behavior during Early Diagenesis: Insights from Mo Isotopes. Geochemistry, Geophysics, Geosystems, 10.

[61] Siebert, C., Nagler, T.F., Blanckenburg, F. and Kramers, J.D. (2003) Molybdenum Isotope Records as a Potential New Proxy for Paleoceanography. Earth and Planetary Science Letters, 211, 159-171. https://doi.org/10.1016/S0012-821X(03)00189-4

[62] McManus, J., Nägler, T., Siebert, C., Wheat, C.G. and Hammond, D.E. (2002) Oceanic Molybdenum Isotope Fractionation: Diagenesis and Hydrothermal RidgeFlank Alteration. Geochemistry, Geophysics, Geosystems, 1078.

https://doi.org/10.1029/2002GC000356

[63] Greber, N.D., Siebert, C., Ngler, T.F. and Petke, T. (2012) ${ }^{98 / 95}$ Mo Values and Molybde-Numconcentration Data for NIST SRM 610, 612 and 3134: Towards a Common Protocol for Reporting Mo Data. Geostandards and Geoanalytical Research, 36, 291-300. https://doi.org/10.1111/j.1751-908X.2012.00160.x

[64] Ryb, U., Erel, Y., Matthews, A., Avni, Y., Gordon, G.W. and Anbar, A.D. (2009) Large Molybdenum Isotope Variations Trace Subsurface Fluid Migration along the Dead Sea Transform. Geology, 37, 463-466. https://doi.org/10.1130/G25331A.1

[65] Barling, J., Arnold, G.L. and Anbar, A.D. (2001) Natural Mass-Dependent Variations in the Isotopic Composition of Molybdenum. Earth and Planetary Science Letters, 193, 447-457. https://doi.org/10.1016/S0012-821X(01)00514-3

[66] Jia, R. (1997) Structure and Oil and Gas Resources in Tarim Basin China. Petroleum Industry Press, Beijing, 438. (In Chinese).

[67] Kirschvink, J.L., Ripperdan, R.L. and Evans, D.A. (1997) Evidence for a Large-Scale Reorganization of Early Cambrian Continental Masses by Inertial Interchange True polar Wander. Science, 277, 541-545. https://doi.org/10.1126/science.277.5325.541

[68] Gao, Z.Q. and Fan, T.L. (2012) Extensional Tectonics and Sedimentary Response of the Early-Middle Cambrian Passive Continental Margin, Tarim Basin, Northwest China. Geoscience Frontiers, 3, 661-668. https://doi.org/10.1016/j.gsf.2012.01.007

[69] Archer, C. and Vance, D. (2008) The Isotopic Signature of the Global Riverine Molybdenum Flux and Anoxia in the Ancient Oceans. Nature Geoscience, 1, 597-600. https://doi.org/10.1038/ngeo282

[70] Amthor, J.E., Grotzinger, J.P., Schroder, S., Bowring, S.A., Ramezani, J., Martin, M. W. and Matter, A. (2003) Extinction of Cloudina and Namacalathus at the Precambrian-Cambrian Boundary in Oman. Geology, 31, 431-434. https://doi.org/10.1130/0091-7613(2003)031<0431:EOCANA>2.0.CO;2

[71] Shields, G. and Stille, P. (2001) Diagenetic Constraints on the Use of Cerium Anomalies as Palaeoseawater Redox Proxies: An Isotopic and REE Study of Cambrian Phosphorites. Chemical Geology, 175, 29-48.

https://doi.org/10.1016/S0009-2541(00)00362-4 
[72] Lehmann, B., Nägler, T.F., Holland, H.D., Wille, M., Mao, J.W., Pan, J.Y., Ma, D.S. and Dulski, P. (2007) Highly Metalliferous Carbonaceous Shale and Early Cambrian Seawater. Geology, 35, 403-406. https://doi.org/10.1130/G23543A.1

Submit or recommend next manuscript to SCIRP and we will provide best service for you:

Accepting pre-submission inquiries through Email, Facebook, LinkedIn, Twitter, etc. A wide selection of journals (inclusive of 9 subjects, more than 200 journals)

Providing 24-hour high-quality service

User-friendly online submission system

Fair and swift peer-review system

Efficient typesetting and proofreading procedure

Display of the result of downloads and visits, as well as the number of cited articles

Maximum dissemination of your research work

Submit your manuscript at: http://papersubmission.scirp.org/

Or contact ijg@scirp.org 